\title{
Factors that influence employee perceptions about performance management at Statistics South Africa
}

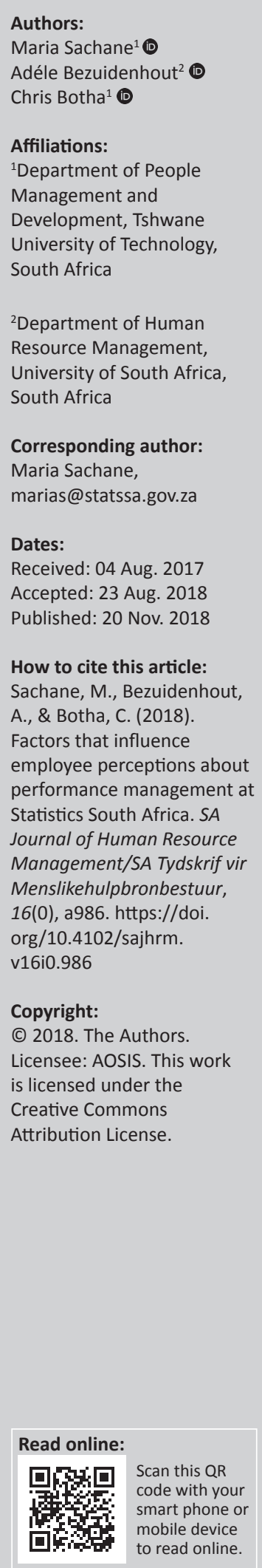

Orientation: The implementation of performance management (PM) in the public sector remains a challenge and requires an investigation into employees' perception of PM at Statistics South Africa.

Research purpose: This study investigates the factors that affect employee performance at Statistics South Africa with the aim of providing a management framework for improving the performance of employees.

Motivation for the study: The motivation for this study was to identify factors that affect employees' perception of PM at Statistics South Africa. By ascertaining these factors, it may be possible to influence the performance of employees positively.

Research approach/design and method: The study followed a quantitative research approach using an explorative and descriptive design. The population consisted of 3326 employees. The random sample drawn contained 444 respondents, and the realised sample had 303 respondents. This represented a response rate of $68 \%$. Data were collected through a Likertscale-type questionnaire.

Main findings: The results showed that employees perceived PM as ineffective and unfair. Various factors affecting PM at Statistics South Africa negatively were revealed. The analysis of the research identified the following performance factors: communication, talent management, retention, recruitment and selection, engagement and motivation.

Practical/managerial implications: The findings revealed that employees were not involved in the development and the implementation of PM. Managers and supervisors who are not committed to the PM of their subordinates avoid performance contracting and the conducting of performance reviews. Managers should be encouraged to give feedback to employees and to see PM as a development tool, rather than a compliance matter.

Contribution/value-add: The research study contributes to the understanding of the perception of employees of Statistics South Africa regarding the factors that positively or negatively affect the PM process.

\section{Introduction}

This study focuses on the factors that influence the perception of performance management (PM) at Statistics South Africa with the aim of providing a management framework for improving the performance of employees. Performance management combines and coordinates an organisation's efforts to grow or become more efficient by motivating employees through evaluation, development, reward and promotion (Watkins \& Leigh, 2010, p. 99). According to Castello (1994, p. 6), when employees are clear about what is expected of them, and have the necessary support to contribute to an organisation efficiently and productively, their sense of purpose, self-worth and motivation will increase. As the majority of employees in Statistics South Africa, who have not entered into performance agreements, may be uncertain whether they are performing in terms of the expectations of their jobs, this will impact negatively on the organisational performance. By entering into a performance agreement will help the supervisors and team members within Statistics South Africa to set performance standards and measure the achievements in terms of these set standards.

This article reports on a study conducted among employees of Statistics South Africa to measure the impact of PM. Six factors, namely communication, motivation, retention, recruitment and selection, engagement and talent management were used to measure the PM in this study. The study highlights how these variables influence performance positively or negatively. 
The objectives of this study are, firstly, to determine those factors that impact positively or negatively on PM at Statistics South Africa. Secondly, the study aims to verify how various demographic groups differ in terms of their perception of PM at Statistics South Africa. Thirdly, the article aims to make conclusions and recommendations on employee perceptions of PM at Statistics South Africa.

This study contributes to the effectiveness of PM by providing a theoretical framework of the factors that influence the effectiveness of PM of employees at Statistics South Africa.

\section{Research questions}

The research questions included the following:

- What are the factors that impact on PM at Statistics South Africa?

- How do various demographic groups compare in terms of their perception of PM at Statistics South Africa?

- What conclusions and recommendations can be made on employee perceptions of PM at Statistics South Africa?

\section{Current trends in the literature}

Performance management arrived in the latter part of the 1980s, partly as a reaction to the negative experience of merit rating and management by objectives. Its strength is that it is essentially an integrated approach to managing performance on a continuous basis. The appeal of PM in its authentic form is that it is holistic. It pervades every aspect of running the business and helps to give purpose and meaning to those involved in achieving organisational success (Armstrong, 2009, p. 25).

According to Koontz as quoted by Armstrong (2009, pp. 10$11)$, the first known example of performance appraisal took place during the Wei Dynasty (AD 221-65) when the emperor employed an 'imperial rater' whose task was to evaluate the performance of the official family. In the 16th century, Ignatius Loyola established a system for formal rating of the members of the Jesuit society. The first formal monitoring systems, however, evolved out of the work of Frederick Taylor and his followers before the First World War.

Management by objectives then came into being during the 1960s, while the term PM was first used in the 1970s. Performance management has emerged, from the 1990s onwards, as an integral part of the human resource management approach to managing an organisation (Fletcher, 2004, p. 31).

Performance management has become more popular as total quality management programmes emphasised using all the management tools, including performance appraisal. It involves the strategic use of performance measures and standards, and aims to establish performance targets and goals and to improve the effectiveness and efficiency of the organisation (Chen, 2011, p. 33).

Performance management is a critical aspect of organisational effectiveness, yet it is considered the 'Achilles heel' of human capital management and should therefore be a top priority of managers. Less than one-third of employees believe that their company's PM process assists them in improving their performance. Performance management regularly ranks among the lowest topics in employee satisfaction surveys (Gruman \& Sack, 2010, p. 1).

Performance management places key emphasis on improving organisational performance. Putting less emphasis on input and process control, its proponents argue that performance should be the guiding concept in organisational decisionmaking, routines and structures and that strategic planning and performance evaluation should be promoted. The PM model is often represented as a cyclical process in which management focuses primarily on defining organisational goals, setting performance targets and subsequently holding employees accountable. This process is then repeated possibly with adjustments in goals, targets or performance indicators reflecting the experiences of previous cycles (Nielsen, 2018, p. 431). Asamany and Shaorong (2018, p. 57) define PM as a planned and cohesive approach to deliver continuous success to organisations by improving the performance of the employees, by considering the capabilities of teams and individual contributions.

Leonard (2010, p. 342) defines PM as all those things a supervisor must do to enable an employee to achieve prescribed objectives. The above statement is supported by Brown and Steward (2009, p. 284) who mention that PM is the process of measuring, assessing, providing feedback and communicating about employees' contribution to the organisation. From the literature studied, it can thus be deduced that measuring performance and providing feedback does indeed improve employee performance.

Performance management forms part of a more comprehensive organisation development approach, referred to as the PM system (PMS). Ferreira and Otley (2009) state that the term 'PMS' refers to:

formal and informal mechanisms, processes, systems, and networks used by organisations for conveying the key objectives and goals elicited by management, for assisting the strategic process and ongoing management through analysis, planning, measurement, control, rewarding, and broadly managing performance, and for supporting and facilitating organizational learning and change. (p. 264)

Performance management system thus refers to broad, overall, ongoing processes including formal practices, procedures processes and systems, as well as the informal actions and procedures. The focus of this study was specifically on PM which can be seen as an important element of the PMS.

In most organisations, nationally and internationally, the PM cycle is a process that stretches over a 12-month period during which performance is planned, executed and assessed. In Statistics South Africa, it must be aligned to the organisation's annual business plan, which is from 1st April to 31st March of the following year. The 12-month cycle is 
also linked to the financial year for the purpose of planning, pay progression and other performance-related incentives such as performance awards or cash bonuses. The probation cycle, however, is linked to the appointment date of a jobholder (Department of Public Service \& Administration, 2007, p. 11; Department of Statistics South Africa, 2003, p. 6).

Williams (2002, p. 16) and the Department of Public Service and Administration (2007, p. 11) identify factors that are closely related to the PM cycle in the South African context, such as (1) performance planning and agreement, (2) performance monitoring, developing and control and (3) performance appraisal. These factors are explained as follow:

- The performance agreement is the cornerstone of PM at the individual level. All employees must enter into and sign performance agreements before the end of the first quarter of the new cycle. The performance agreement format applies to all levels (salary levels 1-16) in the Department of Statistics South Africa and the contents must reflect the department's strategic and annual operation plan, business plans and job descriptions, job roles and actual activities and responsibilities (Department of Public Service and Administration, 2007, p. 11).

- Individual performance must continuously be monitored to enable the identification of performance barriers and changes and to address development and improvement needs as they arise as well as to determine progress and/or identify obstacles in achieving objectives and targets (Department of Public Service and Administration, 2007, p. 15).

- Performance appraisal begins by identifying objectives, recognising the benefits for all concerned, and identifying key criteria (Arthur, 2008). It is a process that is commonly used throughout many organisations to evaluate or appraise employee's performance in the past and to consider how to maximise the employee's future contributions (Banfield \& Kay, 2012, p. 295). Unfortunately, employees often have doubt about the accuracy of their performance appraisals (Decenzo \& Robbins, 2002, p. 280). Swan and Wilson (2007, pp. 21-27) identified a number of reasons of why performance appraisal fail, including inadequately defined standards of performance, an overemphasis on recent performance, reliance on gut feelings, without evidence, an employee's miscomprehension of performance expectations, insufficient performance documentation, inadequate time for the discussion and the lack of a follow-up plan. Further distortions that may affect the review are illustrated in Figure 1 by Decenzo and Robbins (2002, p. 281).

Performance standards are the ways the organisation goes about meeting its mission statement. These may include ethical values and levels of quality (Sandler \& Keefe, 2005, p. 10). Furthermore, Rampersad (2003, pp. 83-85) mentions that a performance target is a quantitative aim of performance measurement. It indicates a value that must be met. $\mathrm{He}$ mentions that targets can be based on the expectations of management, the needs of the customers or the results of

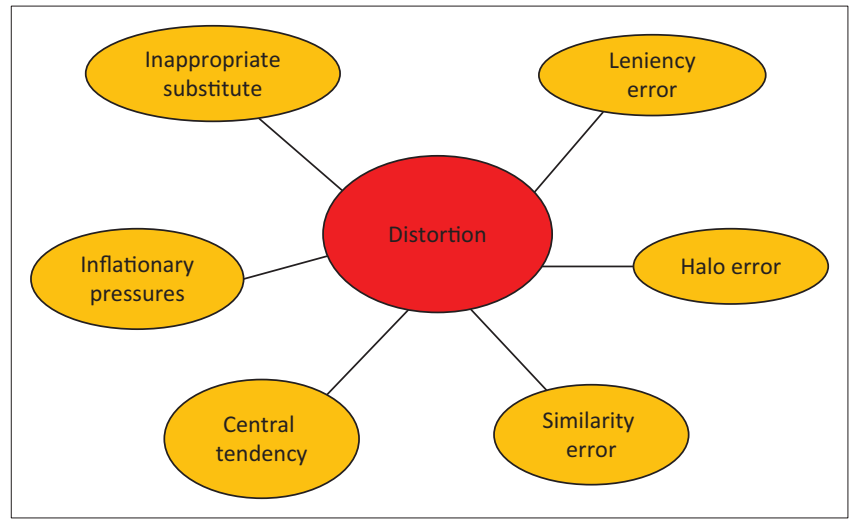

Source: Decenzo, D. A., \& Robbins, S. P. (2002). Human resource management (7th ed.). USA: John Wiley. p. 281

FIGURE 1: Factors that distort appraisals.

benchmark studies. This would both provide management with timely signals that are based on the focused guidance of the organisation according to measurements of change and a comparison of measured results against standards.

Based on a careful revision of the theory available, the researchers have identified the specific factors that may affect $\mathrm{PM}$ at Statistics South Africa. These identified factors formed the basis of the questionnaire that was developed and are explained below:

- Communication: Erasmus-Kritzinger, Bowler and Goliath (2002, p. 3) define communication as a two-way process whereby information (message) is sent from one person (sender) through a channel to another (receiver) who, in turn, reacts by providing feedback. Fyffe (2007, p. 18) supports this notion and explains that communication is a reciprocal process, establishing a dialogue with people in the business, and often results in a better solution that helps to get early engagement and interest in what one is introducing. Leonard (2010, p. 342) emphasises the importance of communicating how well an employee is performing a job, during the PM effort. Silber and Foshay (2010, pp. 412-413) further explain that many PM efforts fail because of poorly managed relationships, including poor communication, between the different stakeholders.

- Talent management is needed for success, effectiveness and consistency. Talent is considered the most critical source of success in an organisation (Phillips \& Edwards, 2009, p. 3). Silzer and Dowell (2010, p. 13) mention that talent in an organisation refers to an individual's skills and abilities (talents) and what the person is capable of doing or contributing to the organisation. Carey, Grobler, Holland and Warnich (2008, p. 128) explain that talent management, which involves the cooperation and communication of managers at all levels, has become an imperative in today's business world. The components of talent management include extensive new employee orientation, use of selection and rewards to align employees with company values, formal management development programmes, careful succession planning and Chief Executive Officer (CEO) selection, investment in human capabilities through recruiting, training and development (Silzer \& Dowell, 2010, p. 5). 
- Recruitment and selection: Martel (2002, pp.77-78) believes that recruiting and hiring are the most critical practices for finding and keeping high performers. The author further mentions that recruiting and retaining good employees have demonstrably measurable results and also mean important cost savings.

- Assessment: Reynolds and Welner (2009, p. 35) explain that when used properly, an organisation has much to gain by incorporating assessment into their talent programmes.

- Training and development: According to Byars and Rue (2008, p. 154), training is the learning process that involves the acquisition of the knowledge, skills and abilities (KSA) necessary to successfully perform a job.

- Retention: Phillips and Edwards (2009, p. 27) define retention as the percentage of employees remaining in the organisation. They explain that high levels of retention are desired in most job groups.

- Reward management: Milne (2007, p. 30) mentions that recognition is a non-financial award given to employees selectively, in appreciation of a high level of accomplishment that is not dependent on achievement against a given target. According to Zhou, Zhang and Montoro-Sanchez (2011, p. 82), reward management is a key function in human resource management systems in modern enterprises, playing an important role in attracting, retaining and motivating employees.

- Engagement: According to Wiley (2010, p. 47), organisations that want to be successful need motivated and engaged employees. Federman (2009, p. 22) defines employee engagement as the degree to which a person commits to an organisation and the impact that commitment has on how well they perform and their length of tenure. Wiley (2010) postulates that a critical element in building confidence, motivating performance and increasing employee engagement is having managers who inspire belief in the organisation's future. He further states that organisations that want to achieve business success need motivated and engaged employees. Managers need to build a culture of motivated employees who are working to achieve business goals.

\section{Method}

\section{Research approach}

A deductive, quantitative-descriptive approach was adopted to examine the impact of PM on employee's performance in Statistics South Africa. This type of research involves identifying the characteristics of an observed phenomenon (Saunders, Lewis, \& Thornhill, 2009, p. 155). A cross-sectional survey design was used to gather primary data from the participants to achieve the objectives of the study. Descriptive research examines a situation as it is. It does not involve changing or modifying the situation under investigation, nor is it intended to determine cause-and-effect relationships (Babbie, 2011, p. 95).

\section{Research design}

\section{Research participants}

As this study examines the impact of factors affecting the employee performance, the employees of Statistics South Africa have been taken as a target population. Simple random sampling was used to select the study subjects from a list of names as this improves the reliability and generalisability of statistical results. According to Blair and Blair (2015, p. 11), probability sampling employs a random process to ensure that each element has the same, known, non-zero chance of selection. The entire population consisted of 3326 elements. The selected sample contained 444 units. In total 444 questionnaires were distributed to both male and female respondents and 303 completed responses were received back. This represents a response rate of $68 \%$.

\section{Measuring instruments}

A questionnaire was compiled based on the theoretical framework, compiled from a close scrutiny of the literature. The questionnaire contained a five-point Likert-type scale instrument, with values ranging from 1 (strongly disagree), 2 (disagree), 3 (neutral), 4 (agree) to 5 (strongly agree) to measure responses. The questionnaire was divided into two sections, namely: Section A required biographic information such as age, gender, language, designation, education, employment and years of service. Section B contained questions in relation to factors affecting PM at Statistics South Africa. The survey consisted of the following factors: talent management, engagement, recruitment and selection, retention, motivation and communication. There were five questions posed in relation to each factor (sub-dimension) and therefore a total of 30 questions were posed to the respondents.

\section{Research procedure}

Permission was obtained from the Statistician-General of Statistics South Africa to distribute the questionnaire to the targeted population. Each questionnaire was accompanied by a covering letter, explaining the purpose of the study, promising confidentiality and voluntary participation, the importance of participation, potential benefits and contact information. The questionnaire was distributed electronically via a link, to those employees who were stationed at head office, as well as those stationed at provincial offices.

\section{Data analysis}

The Statistical Package for Social Sciences (SPSS) version 20.0 was employed for the data analysis. Descriptive analysis includes frequencies and percentages, and reliability tests include Cronbach's alpha (Bouwan \& Ling, 2006, p. 38; Ho, 2006, p. 26). Furthermore, factor analysis was applied to discover patterns among the variations in values of several variables. Pearson's chi-square was used to test the statistical significance (Curtis \& Curtis, 2011, p. 157) with the $p$-value of the chi-square test, specifically with regard to demographical variables.

The factors that emerged are demonstrated in Table 1. 
TABLE 1: Rotated factor pattern of the factor analysis.

\begin{tabular}{|c|c|c|c|c|c|c|c|}
\hline Rotated factor pattern & Factor 1 & Factor 2 & Factor 3 & Factor 4 & Factor 5 & Factor 6 & Factor 7 \\
\hline 'There is communication channels in my organisation.' & 0.802 & - & - & - & - & - & - \\
\hline 'I can to share meaning through communication.' & 0.782 & - & - & - & - & - & - \\
\hline Employees always receive feedback.' & 0.770 & - & - & - & - & - & - \\
\hline 'I feel at liberty to communicate with management.' & 0.704 & - & - & - & - & - & - \\
\hline 'At work, my opinions seem to count.' & 0.644 & - & - & - & - & - & - \\
\hline 'My organisation communicates about change management.' & 0.549 & - & - & - & - & - & - \\
\hline I am satisfied with my organisation. & 0.475 & - & - & - & - & - & - \\
\hline 'HRM provides information relating to talent.' & - & 0.793 & - & - & - & - & - \\
\hline 'A rotation process exists to rotated talent.' & - & 0.752 & - & - & - & - & - \\
\hline 'Talent management system attracts talent.' & - & 0.719 & - & - & - & - & - \\
\hline 'Natural talents have been assessed.' & - & 0.579 & - & - & - & - & - \\
\hline 'Rotation process to rotate talents.' & - & - & 0.747 & - & - & - & - \\
\hline 'Management contributes to retention of employees.' & - & - & 0.738 & - & - & - & - \\
\hline 'My organisation is aware that the employee turnover impacts negatively on its service delivery.' & - & - & 0.681 & - & - & - & - \\
\hline 'Job-related questions were posed during the interview.' & - & - & - & 0.764 & - & - & - \\
\hline 'I believe that R\&S policy at Statistics South Africa is clear.' & - & - & - & 0.661 & - & - & - \\
\hline 'The advert gave the information I needed about the position.' & - & - & - & 0.653 & - & - & - \\
\hline 'I did receive acknowledgement of receipt of my application.' & - & - & - & 0.518 & - & - & - \\
\hline 'I believe that HRM provides good service.' & - & - & - & 0.439 & - & - & - \\
\hline 'My colleagues work equally as hard as I do.' & - & - & - & - & 0.721 & - & - \\
\hline 'My fellow employees are committed to doing quality work.' & - & - & - & - & 0.691 & - & - \\
\hline 'I feel remuneration is always motivating.' & - & - & - & - & 0.486 & - & - \\
\hline 'I know what is expected of me at work. & - & - & - & - & - & 0.755 & - \\
\hline 'I feel I do my job up to standard.' & - & - & - & - & - & 0.490 & - \\
\hline 'In the last 7 days, I have received recognition or praise.' & - & - & - & - & - & - & 0.643 \\
\hline 'I use my natural talents daily by doing what I do best.' & - & - & - & - & - & - & 0.551 \\
\hline 'My supervisor encourages my self-development and learning.' & - & - & - & - & - & - & 0.510 \\
\hline
\end{tabular}

PM, performance management; R\&S, recruitment and selection; HRM, human resource management.

TABLE 2: Cronbach's alpha for six factors affecting performance management at Statistics South Africa.

\begin{tabular}{llcc}
\hline Factor & Scale & $\begin{array}{c}\text { Cronbach's alpha based } \\
\text { on standardised items }\end{array}$ & No. of items \\
\hline Factor 1 & Communication & 0.885 & 5 \\
Factor 2 & Talent management & 0.834 & 5 \\
Factor 3 & Retention & 0.819 & 5 \\
Factor 4 & Recruitment and selection & 0.750 & 5 \\
Factor 5 & Engagement & 0.768 & 5 \\
Factor 6 & Motivation & 0.714 & 5 \\
\hline
\end{tabular}

As one of the seven initial factors had only two items loading on it (the initial factor 6), it was not retained. As a rule of thumb, there should be at least three items loading on a factor for meaning interpretations to be made (Walsh, 1990). As a result, the final factor analysis above shows that factor 1 represents communication, factor 2 represents talent management, factor 3 represents retention, factor 4 represents recruitment and selection, factor 5 represents engagement and factor 6 represents motivation. In addition to the factor analysis, the Cronbach's alpha statistics for each of the six factors affecting PM at Statistics South Africa were calculated and are presented in Table 2.

The empirical results in Table 2 confirmed the reliability of each of the six retained factors, as all the Cronbach's alpha values were above 0.7 . The empirical results thus confirmed that the factors that affect PM at Statistics South Africa are communication, talent management, retention, recruitment and selection, engagement and motivation. Furthermore, the total variance, explained by each factor, was calculated and is presented in Table 3.
From Table 3, it is noteworthy that communication accounted for the most variance, talent management second most and retention the third most variance in explaining PM at Statistics South Africa.

The Pearson chi-squire statistics, as calculated for the demographical variables, are presented in Table 4.

The results in Table 4 present the results of the Pearson correlation analysis across different demographic groups. Likelihood ratios as well as linear-by-linear associations were calculated for each item, but for the sake of parsimony, the results are summarised in Table 4 . In summary, the results of the statistical analysis showed that different age groups experience similarities in their attitudes towards communication, talent management, retention, engagement and motivation. The genders experience similarities towards the variables recruitment, selection and retention. Employees with different educational levels experience similarities in their attitudes towards engagement, retention and motivation. Different employment classes experience similarities in relation to talent management system, engagement and motivation. Employees with different years of service experience similarities towards talent management, retention and communication.

\section{Discussion}

The first research question was concerned with identifying the factors that affect PM at Statistics South Africa. Six factors 
TABLE 3: Total variance explained by each factor.

\begin{tabular}{lccccc}
\hline $\begin{array}{l}\text { Factor 1: } \\
\text { Communication }\end{array}$ & $\begin{array}{c}\text { Factor 2: } \\
\text { Talent } \\
\text { management }\end{array}$ & $\begin{array}{c}\text { Factor 3: } \\
\text { Retention }\end{array}$ & $\begin{array}{c}\text { Factor 4: } \\
\text { Recruitment } \\
\text { and selection }\end{array}$ & $\begin{array}{c}\text { Factor 5: } \\
\text { Engagement }\end{array}$ & $\begin{array}{c}\text { Factor 6: } \\
\text { Motivation }\end{array}$ \\
\hline 5.0920825 & 3.1284030 & 2.8346709 & 2.3723304 & 1.9961577 & 1.7350634 \\
\hline
\end{tabular}

TABLE 4: Pearson correlations in terms of demographical variables.

\begin{tabular}{lccc}
\hline Pearson chi-square & Value $\uparrow$ & Df & Asymp. sig. (2-sided) \\
\hline Age & 28.949 & 16 & 0.024 \\
Gender & 12.540 & 4 & 0.014 \\
Highest qualification completed & 45.170 & 28 & 0.021 \\
Employment classes & 48.959 & 28 & 0.008 \\
Years of service & 62.673 & 28 & 0.000 \\
\hline
\end{tabular}

$\dagger$, Cronbach alpha.

Asymp. sig., asymptotic significance ( $p$-value); Df, degrees of freedom.

that play a role in employees' perception of PM emerged, namely communication, talent management, retention, recruitment and selection, engagement and motivation. In addition, the empirical study confirmed the reliability of each of these the factors.

The empirical results thus supported the view of Leonard (2010) and Silber and Foshay (2010) that communication is a very important element of PM. As it emerged as the most important factor, it is reasonable to assume that a lack of feedback during PM will have an adverse effect on the acceptance and the success of PM at Statistics South Africa. Furthermore, it is the responsibility of the manager to clearly communicate expectations in the form of performance standards and targets to subordinates. Regular, continuous feedback throughout the period of assessment is essential to improve employee performance and to provide the recognition that will motivate employees to sustain satisfactory performance. Managers have to work continuously at maintaining reciprocal communication channels (Fyffe, 2007), because in order for the performance review and feedback process to work well, there must be a two-way communication process and dialogue, which is the responsibility of both managers and employees, jointly.

As talent is considered the most critical source of success in an organisation (Phillips \& Edwards, 2009), and this study identified talent management as the second most important factor, it can be concluded that talent management is imperative to the PM effort at Statistics South Africa. Managers need to focus on individuals' skills, abilities and talents. Furthermore, successful talent management is impossible without effective communication. There is thus an interaction process between the individual factors at play. The same is true for recruitment and selection, which is integral to talent management interventions, as well as the retention of high performing employees (Martel, 2002). Retaining talented, high performing employees, promote retention of critical skills and organisational performance. The findings of this study supported Wiley's (2010) belief that successful PM practices depend on retaining motivated and engaged employees. By recognising the efforts of high performing employees and clearly communicating the trust in them during PM discussions, managers have the ability to motivate, inspire and retain valuable human capital. The first research question, pertaining to the identification of perceived PM factors at Statistics South Africa, was thus addressed comprehensively.

The second research question sought to investigate how various demographic groups compare in terms of their perception of PM at Statistics South Africa. It is noteworthy that there are many similarities in the way different demographical groups perceive the factors that affect PM at Statistics South Africa. If the first factor, communication, is considered, the empirical results showed that employees of different ages, genders, educational levels and years of service all perceived communication to be an important determinant of PM. The second factor, talent management, was perceived similarly among the employees of different age groups, genders, employment classes and years of service. Also, the third factor, retention, was perceived in the same way by different ages, genders, educational levels, employment classes and years of service. It is encouraging that the results seem to indicate that employees are perceiving PM at Statistics South Africa the same, across different demographical groups, as it may be an indication that all employees are fairly treated in the same manner.

Some of the exceptions that were identified included a discovery that employees indicated a lack of confidence in their prospects of promotion within Statistics South Africa. This may be a contributing factor in the negative perception by respondents towards PM, where the age group 30-39 felt that superior work performance is not recognised. In this study, it was also discovered that employees from the age groups 30-39 and 40-49 felt that the economic climate affects their satisfaction with their salary level to a higher extent, compared to their counterparts. This may be an example of extrinsic motivation, referring to performance that is contingent upon the attainment of an outcome that is separable from the action itself (Legault, 2016, p. 1). Lastly, employees from the age group 40-49 felt more positive about the materials and equipment to do their work effectively and were also more satisfied with the retention process at Statistics South Africa.

The third aim of this article was to make conclusions and recommendations on employees' perception of PM at Statistics South Africa. Based on the human resource management literature reviewed and the empirical results obtained, the following recommendations are made:

- As the results of this study emphasised the importance of communication, managers must focus on providing clear communication on performance expectations and goals. Employees also need continuous constructive feedback on their performance, so that they can adjust their performance as needed informed. Critical decisions and instructions should be communicated timeously to 
promote transparency and keep employees motivated and engaged.

- Performance management as a development tool rather than a compliance matter. When PM is used as a tool to develop employees, it encourages staff motivation by exploring alternative remuneration and reward systems that complement the organisation's traditional rewards.

- Considering the importance of talent management, identified as the second most influential factor in PM at Statistics South Africa, managers must incorporate career management conversations in the PM process. The implementation of the talent management strategy should be fast tracked. Human resource practitioners should encourage job rotation, job shadowing and mentoring programmes to enhance the experience and exposure of high-performance employees at Statistics South Africa. High performing staff can also be considered for secondment to other divisions or departments to gain experience and exposure.

- This study confirmed the importance of fair recruitment and selection practices as a factor in determining employees' perception of the success of PM. Recruitment and selection should be transparent, fair and open in order to motivate internal employees to continuously improve their performance.

- Although not all good performances can be rewarded through promotion, an effective remuneration strategy can introduce other forms of recognition of superior performance. An example could be a 'staff awards day' where high performing employees are publicly commended and recognised by the Head of Department. Certificates and small cash awards can be given with clear citations of the reason for the award. This could address both the motivation and employee engagement factors that determine employee's perception of PM. If employees understand what is expected, invest effort in improving their performance and then receive recognition, their perception of PM will improve.

\section{Practical implications}

This study has identified significant factors that affect employee's performance at Statistics South Africa. The findings of this research show that management people are not committed to their PM of their subordinate. This weakness about the lack of participation for the employees should be addressed to ensure that employees perceive the PM process as fair.

\section{Limitations}

Limited prior research findings on employees' perception of PM at Statistics South Africa were available. A self-report questionnaire was used and the answers were dependent on employees' memories. The sample was influenced by some employees being on maternity and vacation leave.

\section{Recommendations}

The results of this study revealed the positive and negative factors affecting PM in Statistics South Africa. These factors need to be addressed to ensure a gradual sustainable progress in improving the performance of employees within Statistics South Africa. Further research can be conducted in the following areas:

- This investigation can be expanded by doing research at other government departments.

- The perception of employees of PM within Statistics South Africa is in a broader perspective.

- Further research is needed to validate these results in a few government departments.

\section{Conclusion}

The study has identified unique factors that affect PM at Statistics South Africa. It was therefore concluded that:

- Most of the employees within Statistics South Africa believe that talent management is a challenge. This is an area which the management of Statistics South Africa should address. Statistics South Africa should introduce a system that will be able to attract the competent employee in order to avoid staff turnover.

- More than half of the employees maintain that there is no job rotation process in Statistics South Africa. It can be concluded that the majority of the respondents within Statistics South Africa believe that there is no job rotation process in the organisation, which is a concern that the organisation should address.

- Nearly half of the employees responded negatively regarding information related to a talent management system. This may be regarded as a negative response that reveals that the human resource processes regarding talent management are not clear to the employees. This is an area in which management must ensure that they conduct workshops with their employees to create an awareness of the policies that affect employees within the organisation.

- Some employees claim that their abilities are not assessed by the organisation. Management fails to implement a retention policy and strategy.

- A perceived lack of positive contributions from management towards the retention of employees within the organisation exists. Some employees responded that the organisation's performance reviews and rewards are not effective. Opportunities for promotion are not adequate. Further to that, employees do not receive recognition for doing good work. There is a lack of feedback from management.

\section{Acknowledgements}

The authors would like to thank the Statistician-General Dr Pali Lehohla for granting permission to distribute the questionnaires to the targeted employees, statisticians who have analysed the data as well as the respondents who completed the questionnaires.

\section{Competing interests}

The authors declare that they have no financial or personal relationship that may have inappropriately influenced them in writing this article. 


\section{Authors' contributions}

M.S. was the principal investigator responsible for the fieldwork. A.B. and C.B. were involved in helping to design and supervise the project.

\section{References}

Armstrong, M. (2009). Armstrong's handbook of human resource management practice (11th ed.). London: Kogan Page.

Arthur, D. (2008). The first time managers guide to PA. New York: American Management Association.

Asamany, A., \& Shaorong, S. (2018). The ripple effects of performance management on employees' perceptions and effective commitment among small and medium scale enterprises. China: Saedu Press.

Babbie, E. (2011). The basic of social research (5th ed.). USA: Cengage Learning.

Banfield, P., \& Kay, R. (2012). Introduction to human resource management (2nd ed.) New York: Oxford University.

Blair, E., \& Blair, J. (2015). Applied survey sampling. Los Angeles, CA: Sage.

Bouwan, G. D., \& Ling, R. (2006). The research process (5th ed.). Singapore: Oxford University.

Brown, K. G., \& Steward, G. L. (2009). Human resource management. Linking strategy to practice. Hoboken, NJ: John Wiley.

Byars, L. L., \& Rue, L. W. (2008). Human resource management (10th ed.). New York: McGraw-Hill.

Carey, B. C., Grobler, L., Holland, P., \& Warnich, P. J. (2008). Contemporary issues in human resource management ( $3 \mathrm{rd}$ ed.). South Africa: Oxford University Press Southern Africa.

Castello, S. J. (1994). Effective performance management. Burr Ridge, IL: Business One Irwin.

Curtis, B., \& Curtis, C. (2011). Social research. A practical introduction. Washington DC: Sage.

Chen, X. (2011). Assessment of performance appraisal process (Unpublished Master's thesis). Western Cape: University of Western Cape.

Decenzo, D. A., \& Robbins, S. P. (2002). Human resource management (7th ed.). USA John Wiley.

Department of Public Service and Administration. (2007). Employee performance and development system. Pretoria: Department of Public Service and Administration.

Department of Statistics South Africa. (2003). Monitoring and improving our performance for service delivery. Pretoria: Department of Statistics South Africa.

Erasmus-Kritzinger, L. E., Bowler, A., \& Goliath, D., (2002). Effective communication. Getting the message across in business. Chicago, IL: Afritech.

Federman, B. (2009). Employee engagement. A roadmap for creating profits, optimizing performance, and increase loyalty. San Francisco, CA: Jossey-Bass.
Ferreira, A., \& Otley, D. 2009. The design and use of performance management systems: An extended framework for analysis. Management Accounting Research, 20, 263-282. https://doi.org/10.1016/j.mar.2009.07.003

Fletcher, C. (2004). Appraisal and feedback. Making performance review work. London: CIPD.

Fyffe, R. 2007. Communicating total reward at O2. Human Resource Management International Digest, 15(3), 18-20. https://doi.org/10.1108/09670730710743952

Gruman, J. A., \& Saks, A. M. (2010). Performance management and employee engagement. Human Resource Management Review, 21(2), 123-136. https://doi. org/10.1016/j.hrmr.2010.09.004

Ho, R. (2006). Handbook of univariate and multivariate data analysis and interpretation with SPSS. New York: Chapman \& Hall.

Leonard, E. G., Jr., III. (2010). Supervision concepts and practices of management. USA South Western Gengage Learning.

Martel, L. (2002). High performers. How the best companies find and keep them. San Francisco, CA: Jossey-Bass.

Milne, P. (2007). Motivation, incentives and organizational culture. Journal of Knowledge Management, 11(6), 28-38. https://doi.org/10.1108/13673270710832145

Nielsen, P. A. (2018). Performance management, managerial authority, and public service performance. Journal of Public Administration Research and Theory, 24(2), 431-458. https://doi.org/10.1093/jopart/mut025

Phillips, J. A., \& Edwards, L. (2009). Managing talent retention and ROI approach. San Francisco, CA: Pfeiffer.

Rampersad, H. K. (2003). Total performance scorecard. Redefining management to achieve performance with integrity. Amsterdam: Butterworth- Heinemann.

Reynolds, D. H., \& Welner, J. A. (2009). Online recruitment and selection: Innovation in talent acquisition. United Kingdom: Wiley-Blackwell.

Sandler, C., \& Keefe, J. (2005). Performance appraisals that work: Features 150 samples for every situation. Corey Sandler \& Janice Keefe. Avon, MA: Adams.

Saunders, M., Lewis, P., \& Thornhill, A. (2009). Research methods for business students (5th ed.). New York, Prentice Hall: Pearson Education.

Silber, K. H., \& Foshay, W. R. (Eds.). (2010). Handbook of improving performance in the workplace, volume1: Interactional design and training delivery. San Francisco, CA: Pfeiffer.

Silzer, R., \& Dowell, B. E. (2010). Strategy-driven talent management. A leadership imperative. San Francisco, CA: Jossey-Bass.

Swan, W. S., \& Wilson, L. E., (2007). Ready to use performance appraisal. New York, USA: Wiley.

Walsh, A. (1990). Statistics for the social sciences. New York, USA: Harper \& Row.

Watkins, R., \& Leigh, D., (2010). Handbook of improving performance in the workplace. Vol. 2. Selecting and implementing performance interventions. New York USA: Pfeiffer.

Wiley, J. W. (2010). The impact of effective leadership on employee engagement. New York, USA: Wiley InterScience.

Williams, R. S. (2002). Managing employee performance. Design and implementation in organisation. USA: Thomson.

Zhou, Y., Zhang, Y., \& Montoro-Sanchez, A. (2011). Utilitarianism or romanticism: The effect of rewards on employees' innovative behavior. International Journal of Manpower, 32(1), 81-98. https://doi.org/10.1108/01437721111121242 